\title{
EASTERN POLAND AS THE BORDERLAND OF THE EUROPEAN UNION ${ }^{1}$
}

\author{
TOMASZ KOMORNICKI \\ Institute of Geography and Spatial Organization, Polish Academy of Sciences, \\ Warsaw, Poland \\ AndRZEj MiszczuK \\ Centre for European Regional and Local Studies EUROREG, University of Warsaw, \\ Warsaw, Poland \\ Manuscript received May 28, 2010 \\ Revised version June 7, 2010
}

Komornicki T. \& Miszczuk A., Eastern Poland as the borderland of the European Union. Quaestiones Geographicae 29(2), Adam Mickiewicz University Press, Poznań 2010, pp. 55-69, 3 Figs, 5 Tables. ISBN 978-83-2322168-5. ISSN 0137-477X. DOI 10.2478/v10117-010-0014-5.

ABSTRACT. The purpose of the present paper is to characterise the socio-economic potentials of the regions situated on both sides of the Polish-Russian, Polish-Belarusian and Polish-Ukrainian boundaries (against the background of historical conditions), as well as the economic interactions taking place within these regions. The analysis, carried out in a dynamic setting, sought to identify changes that have occurred owing to the enlargement of the European Union (including those associated with the absorption of the means from the pre-accession funds and from the structural funds). The territorial reach of the analysis encompasses four Polish units of the NUTS 2 level (voivodeships, or "voivodeships"), situated directly at the present outer boundary of the European Union: Warmia-Mazuria, Podlasie, Lublin and Subcarpathia. Besides, the analysis extends to the units located just outside of the eastern border of Poland: the District of Kaliningrad of the Russian Federation, the Belarusian districts of Hrodna and Brest, as well as the Ukrainian districts of Volyn, Lviv and Zakarpattya.

KeYWORDS: Border regions, borderland, Eastern Poland, European integration, foreign trade, border traffic

Tomasz Komornicki, Institute of Geography and Spatial Organization, Polish Academy of Sciences, ul. Twarda 51/55, 00-818 Warszawa, Poland, e-mail: t.komorn@twarda.pan.pl

Andrzej Miszczuk, Centre for European Regional and Local Studies EUROREG, University of Warsaw, ul. Krakowskie Przedmieście 30, 00-927 Warszawa, Poland, a.miszczuk@uw.edu.pl

1 The paper is party based on the report „Eastern provinces of Poland as the borderland of the European Union” prepared for the University of Bordeaux in 2008. Some results of the ESPON 1.4.4. Project were also used. 


\section{Introduction}

In May 2004 the eastern and north-eastern boundary of Poland (including the Polish-Russian segment of $210 \mathrm{~km}$, the Polish-Belarusian segment of $418 \mathrm{~km}$, and the Polish-Ukrainian one of $535 \mathrm{~km}$ ) became the outer boundary of the European Union, and in December of 2007 - the boundary of the extended Schengen zone. This has had a significant influence on the socioeconomic situation of the border areas, some of which were economically the weakest regions of the European Union in the years 2004-2007 (until the accession of Romania and Bulgaria). The purpose of the present paper is to characterise the socio-economic potentials of the regions situated on both sides of the Polish-Russian, Polish-Belarusian and Polish-Ukrainian boundaries (against the background of historical conditions), as well as the economic interactions taking place within these regions. The analysis was carried out in a dynamic setting and sought to identify changes that have occurred owing to the enlargement of the European Union. The territorial reach of the analysis encompasses four Polish units of the NUTS 2 level (voivodeships, or "voivodeships"), situated directly at the present outer EU boundary: Warmia-Mazuria, Podlasie, Lublin and Subcarpathia. Besides, the analysis extends to the units located just beyond the eastern border of Poland: the District of Kaliningrad in the Russian Federation, the Belarusian districts of Hrodna and Brest, as well as the Ukrainian districts of Volyn, Lviv and Zakarpattya. The analysis of cross-border traffic encompasses the segments of the boundary of Poland with Russia, Belarus and Ukraine, and partly also with Lithuania (an internal EU boundary), since transit traffic from the Baltic states directly influences the situation in the Polish border regions.

The article uses the statistical material coming from the Polish Central Statistical Office (GUS), Main Headquarters of the Border Guards, Customs Department of the Ministry of Finance, as well as the statistical institutions of Russia, Belarus and Ukraine. Reference was also made to the results of other analyses and the existing literature of the subject.

\section{Historical conditions}

The Polish segment of the current eastern boundary of the European Union is a typical subsequent boundary (having emerged as secondary with respect to the forms of spatial development; Harsthorne 1936). The political order established in Europe after World War II included expanding the territory of the Soviet Union to include, in particular, Ukraine, Belarus and the Baltic states, as well as creating a belt of countries subordinated to the USRR, with Poland as one of those countries of so-called 'popular democracy'. Consequently, an internal and an external empire took shape separated, among other, by the Polish-Soviet boundary, both treated as the exclusive zone of influence of the Soviet Union (Rościszewski 1993). Poland shifted towards the West, but lost much more territory in the East. Of six towns with more than 200,000 inhabitants each in 1939, two, Vilnius and Lviv, remained outside the new borders of Poland. The ultimate territorial loss amounted to roughly $80,000 \mathrm{sq}$. $\mathrm{km}$. The Polish-Soviet border approached the main cities of the area here analysed to a (straight line) distance of $40 \mathrm{~km}$ (Białystok) and $70 \mathrm{~km}$ (Lublin, Olsztyn, Rzeszów).

In the period 1945-1989 the boundary with the Soviet Union was characterised by a very low degree of permeability. It constituted in a way a 'second iron curtain' separating the socialist countries of Central Europe from their 'Big Brother'. With time, limitations in cross-border traffic became even stricter than when travelling to Western Europe. Thus, in place of a total of 63 railway and road routes which crossed in 1939 the future boundary with the USSR, at the beginning of the 1980s Poland was connected with the Soviet Union by just two road crossings and three generally accessible railway crossings across the border of a total length of $1310 \mathrm{~km}$. There were a couple of other railway border crossings which were used for cargo traffic and military transport. There was an official Polish-Soviet agreement on the non-visa traffic. In reality, though, in order to cross the border one had to show a formally confirmed invitation After 1989 the interpretation of these regulations changed. A voucher, confirming the purchase of tourist services (in both directions) 
could be issued even by a small private company. Consequently, such a document could be purchased at the very border for an equivalent of two dollars. In such a case, usually, the document was actually ineffective. Thereby, the boundary was opened. There followed a decade of fast increase in traffic and cross-border trade. Transit grew as well. New border crossings were opened. At the same time, on the eastern side, significant fragments of the border security infrastructure from the Soviet period were preserved, and starting with the end of the 1990s Poland began modernising its own installations (including the construction of a network of watch towers) in preparation for membership of the European Union.

The successors to the Polish-Soviet agreement on the non-visa cross-border traffic were the independent states of Russia, Lithuania, Belarus and Ukraine. In the years that followed, Poland signed new agreements (based on principles similar to those valid with respect to the countries of Western Europe) with Lithuania and Ukraine. In the traffic with Russia and Belarus, the old agreement stood valid until October 2003. At that time, Poland, obliged by the European Union regulations, renounced the old agreements with Russia and Belarus as well as the new agreement with Ukraine, and introduced visas for the citizens of those countries (also for the citizens of Moldavia, not neighbouring upon Poland). Russia and Belarus, in a countermove, introduced visas for Poles, while Ukraine did not. In December 2007 Poland and Lithuania entered the Schengen zone. The boundary with Russia, Belarus and Ukraine be- came the boundary of this zone. It still functions in the fragmengrational mode with regard to the Polish-Russian, Polish-Belarusian and PolishUkrainian borderland, meaning that it opens to some factors or that it is open in a different degree with respect to particular countries (Moraczewska 2008).

\section{The socio-economic situation of the Polish border regions}

A long period of functioning of the eastern boundary of Poland as the impermeable spatial barrier caused the regions situated along it to take on peripheral features in socio-economic terms. From the demographic standpoint (Table 1), the eastern regions of Poland display a low population density, except for Subcarpathia. The domination of the rural population in the total population number persists in the voivodeships of Lublin and Podlasie. Generally, these are regions of population outflow, and in addition, in the voivodeships of Lublin, Podlasie and Warmia-Mazuria there are significant areas featuring natural population losses. It is also characteristic of the study area that its population is ethnically and nationally diversified. Thus, Podlasie is home of a Belarusian minority (in Białystok, and in the poviats of Bielsk Podlaski, Hajnówka and Siemiatycze), and a Lithuanian minority (the municipalities of Puńsk and Sejny), while in Subcarpathia, Lublin and Warmia-Mazuria a Ukrainian minority lives along with the Polish majority.

Table 1. Population of the eastern borderland of Poland as of December 31st, 2008: the demographic aspect

\begin{tabular}{|l|c|c|c|c|c|c|}
\hline \multicolumn{1}{|c|}{ Voivodeship } & $\begin{array}{c}\text { Population } \\
\text { in `000 }\end{array}$ & $\begin{array}{c}\text { Population den- } \\
\text { sity (persons } \\
\text { per sq. } \mathbf{~ k m ) ~}\end{array}$ & $\begin{array}{c}\text { Population } \\
\text { number change } \\
\mathbf{2 0 0 0}=\mathbf{1 0 0} \%\end{array}$ & $\begin{array}{c}\text { Urbanisation } \\
\text { indicator } \\
\text { in \% }\end{array}$ & $\begin{array}{c}\text { Natural } \\
\text { increase } \\
\text { in \%0 }\end{array}$ & $\begin{array}{c}\text { Net } \\
\text { migration } \\
\text { in \%o }\end{array}$ \\
\hline Lublin & 2161.8 & 86 & 98.0 & 46.5 & -0.2 & -2.0 \\
\hline Subcarpathia & 2099.5 & 118 & 999 & 40.9 & 1.9 & -1.1 \\
\hline Podlasie & 1191.5 & 59 & 98.4 & 59.6 & 0.3 & -1.4 \\
\hline Warmia-Mazuria & 1427.1 & 59 & 100.0 & 59.9 & 2.5 & -2.2 \\
\hline Poland & 38135.9 & 122 & 99.7 & 61.1 & 0.9 & -0.4 \\
\hline
\end{tabular}

Source: own compilation on the basis of data from the Bank of Regional Data (BDR) of the Central Statistical Office (GUS). 
When analysing the education structure of the population aged 15-64 (Table 2), one can notice an alarmingly high percentage of persons with just primary education in Warmia-Mazuria, a relatively high percentage of persons with secondary education in Podlasie, and with higher education in the voivodeships of Lublin and Podlasie. The latter is an effect of the impact of large university centres. Lublin is the biggest and oldest university centre in eastern Poland. An important role in this area is also played by Białystok, Rzeszów and Olsztyn. The biggest universities here are the Warmia-Masuria University in Olsztyn $(34,100$ students), Marie Curie-Skłodowska University in Lublin $(29,500$ students), the University of Rzeszów (21,700 students), the John Paul II Catholic University in Lublin (17,400 students), and the University in Białystok (13,100 students). Besides, a dozen or so private college- or universitylevel schools have been established in the area in response to the growing demand of the transformation period. The gross student enrolment $\mathrm{CO}^{-}$ efficient for the age group of 19-24 increased in Poland from $13.1 \%$ in the academic year 1990/91 to $48.1 \%$ in $2004 / 2005$, reaching one of the highest indicator values of university level enrolment in Europe (see Węcławowicz et al. 2006).

The lowest occupational activity of the population of the working age is observed in the voivodeship of Warmia-Mazuria, where the highest unemployment rate is recorded as well. This is partly associated with the effects of the liquidation of state farms established after World War
II primarily on the formerly German territories. The farmhands from the liquidated farms became jobless, as a rule permanently. The employment structure indicates a very high significance of agriculture in the economies of the voivodeships of Lublin and Podlasie, and somewhat lower in Subcarpathia. Sector II plays an important role in the voivodeships of Subcarpathia and WarmiaMazuria, while sector III - in Warmia-Mazuria, the latter resulting to a large extent from the tourist character of the voivodeship. When one compares the data analysed with the average employment structure in the EU-27 (I - 6.2\%, II $-27.7 \%$, III $-66.1 \%$ ), the claim of the economic backwardness of eastern Poland appears to be demonstrated.

As we pass on to the characterisation of the economy in terms of the synthetic development yardstick of the per capita GDP commonly accepted in the EU (Table 3), we can state that the four eastern voivodeships of Poland are very poorly developed, since none of them exceeded $40 \%$ of the EU-27 average, and they occupy the following ranks: Lublin - $258^{\text {th }}$, Subcarpathia - 257 ${ }^{\text {th }}$, Podlasie $-255^{\text {th }}$, and Warmia-Mazuria $252^{\text {nd }}$ among a total of 268 NUTS 2 regions of the EU-27.

The relatively low labour productivity as measured by the value added per person employed, observed in the voivodeships of Lublin, Subcarpathia and Podlasie, is the result of their outdated economic structure characterised by a high share of farming. At the same time, the

Table 2. Population of the EAstern borderland of Poland: the SOCial aspect

\begin{tabular}{|c|c|c|c|c|c|c|c|c|}
\hline \multirow[t]{2}{*}{ Voivodeship } & \multicolumn{3}{|c|}{$\begin{array}{l}\text { Education structure of persons } \\
\text { aged 15-64 in } 2008\end{array}$} & \multirow{2}{*}{$\begin{array}{c}\text { Rate of } \\
\text { employment of } \\
\text { persons of } \\
\text { working age } \\
\text { in } 2008\end{array}$} & \multicolumn{3}{|c|}{$\begin{array}{l}\text { Employment struc- } \\
\text { ture by sector of } \\
\text { economy in } 2008\end{array}$} & \multirow{2}{*}{$\begin{array}{l}\text { Unem- } \\
\text { ployment rate } \\
\text { as of } 31 \text { Dec. } \\
2008\end{array}$} \\
\hline & primary & secondary & higher & & I & II & III & \\
\hline Lublin & 47.5 & 36.0 & 16.5 & 56.4 & 36.2 & 18.5 & 45.3 & 11.2 \\
\hline Subcarpathia & 48.9 & 36.1 & 15.0 & 53.9 & 23.6 & 28.5 & 47.9 & 13.0 \\
\hline Podlasie & 46.0 & 37.3 & 16.7 & 55.8 & 33.2 & 20.3 & 46.5 & 9.7 \\
\hline Warmia-Mazuria & 54.7 & 31.9 & 13.4 & 52.4 & 15.9 & 29.7 & 54.4 & 16.8 \\
\hline Poland & 47.6 & 35.9 & 16.5 & 55.7 & 15.6 & 28.7 & 55.7 & 9.5 \\
\hline
\end{tabular}

Source: as in Table 1. 
TABLE 3. SYNTHETIC MEASURES OF ECONOMIC DEVELOPMENT OF THE EASTERN BORDERLAND OF POLAND

\begin{tabular}{|c|c|c|c|c|c|c|c|c|}
\hline \multirow{2}{*}{ Voivodeship } & \multicolumn{3}{|c|}{ GDP per capita in 2006} & \multicolumn{3}{|c|}{$\begin{array}{l}\text { Value added per person em- } \\
\text { ployed in } 2006\end{array}$} & \multicolumn{2}{|c|}{$\begin{array}{c}\text { Commercial compa- } \\
\text { nies per } 10,000 \text { popu- } \\
\text { lation in } 2006 \text {, Poland } \\
=100\end{array}$} \\
\hline & $\begin{array}{l}\text { in '000 } \\
\text { Polish } \\
\text { zlotys }\end{array}$ & $\begin{array}{l}\text { Poland } \\
=100\end{array}$ & $\begin{array}{l}\text { at purchasing } \\
\text { power parity } \\
U E-27=100\end{array}$ & $\begin{array}{l}\text { in '000 } \\
\text { Polish } \\
\text { zlotys }\end{array}$ & $\begin{array}{l}\text { Poland } \\
=100\end{array}$ & $\begin{array}{l}\text { UE-27 } \\
=100\end{array}$ & total & $\begin{array}{l}\text { with foreign } \\
\text { capital } \\
\text { participation }\end{array}$ \\
\hline Lublin & 18,779 & 67.6 & 35.3 & 48,008 & 67.9 & 42.8 & 53 & 27 \\
\hline Subcarpathia & 19,024 & 68.4 & 35.8 & 49,929 & 70.6 & 43.6 & 45 & 24 \\
\hline Podlasie & 20,396 & 73.4 & 38.4 & 55,062 & 77.9 & 47.9 & 50 & 24 \\
\hline Warmia-Mazuria & 21,005 & 75.6 & 39.5 & 64,185 & 90.8 & 57.9 & 58 & 41 \\
\hline Poland & 27,799 & 100.0 & 52.3 & 70,696 & 100.0 & 61.2 & 100.0 & 100.0 \\
\hline
\end{tabular}

Source: as in Table 1.

low number of commercial companies per 10,000 inhabitants shows a low level of non-agricultural economic activity of the population, as well as a minimum level of interest in the eastern borderland of Poland on the part of companies with foreign capital participation. The low attractiveness of this territory in terms of investment is also confirmed by the most recent results obtained by the Institute of Study of Market Economy (Kalinowski 2007).

In spatial terms, positive examples of local development are, first of all:

- the already mentioned biggest urban areas that are also university centres;

- special economic zones: the Mielec and Wisłosan Euro-Parks (Subcarpathia voivodeship), the Warmia-Mazuria zone (WarmiaMazuria voivodeship), the Suwałki zone (Podlasie voivodeship);

- regions of modernised agriculture (first of all the dairy region in the western part of Podlasie);

- tourist regions (Mazuria, the Białowieża Forest, the Bieszczady Mts., Roztocze Hills, the Vistula valley); and

- belts along the transit routes leading to the border (mainly serving cargo traffic and petty trade).

A very interesting concept for the development of Subcarpathia voivodeship is the modern cluster of the Aircraft Valley, initiated by the Pratt \& Whitney company, world leader in de- sign, production and servicing of aircraft engines, missile and rocket propulsion systems, and industrial gas turbines. The choice of Subcarpathia was not incidental, since this region is characterised by a high concentration of enterprises of the aircraft industry with almost 100 years of tradition, including the biggest plants in Mielec and Rzeszów, as well as research and development centres led by the Faculty of Machine Construction and Aircraft of the Rzeszów Polytechnic. This undertaking involves around 50 companies, including also a large plant of the aviation industry from Świdnik in the voivodeship of Lublin. For the needs of the Aircraft Valley, the Subcarpathian Scientific-Technological Park, planned to ultimately encompass 400 hectares, was established at the Rzeszów Polytechnic, close to the international airport at Jasionka near Rzeszów.

In the voivodeship of Podlasie, in connection with the regional tradition and agricultural potential of the area (especially in cattle raising) the Podlasie Food Production Cluster was established to enhance the innovativeness and competitiveness of the local companies active in the agri-food branch on the EU market. An interesting initiative involving the use of the agricultural potential and clean environment of Lublin voivodeship is the idea of setting up the Ecological Food Valley, a cluster aimed at satisfying the market demand for the so-called health food, well-developed in the countries of Western Europe and also developing in Poland. 
The pattern of the transport network in Eastern Poland still remains to a high extent as shaped by historical factors. This concerns, first of all, railway transport and the central part of the study area (the voivodeships of Podlasie and Lublin), where railway transport developed in the $19^{\text {th }}$ century within the framework of the transport system of imperial Russia. The network of connections was relatively sparse there, lines were usually straight, and railway stations were located far away from city centres except for the largest cities, also for political reasons, like traffic control (Lijewski 1986). Irrespective of stagnation in terms of investment projects, which lasted virtually during the entire period of the systemic transformation, after 1989 the segments of the road and railway routes crossing Eastern Poland have gained a new, international dimension. They have become elements of the European TNT network and pan-European transport corridors. With time, some of them have been included in the list of transport priorities of the European Union. The TNT network embraces the following corridors in Eastern Poland:

- Warsaw - Terespol - Minsk (a road and railway line), a fragment of the pan-European corridor II;

- Warsaw - Dorohusk - Kiev (a road and railway line);

- Warsaw - Białystok - Trakiszki - Kaunas (a road and railway line, the so-called Via Baltica and Rail Baltica), a fragment of the pan-European corridor I;

- Cracow - Medyka - Lviv (a road and railway line), a fragment of the pan-European corridor III;

- Gdańsk - Elbląg - Kaliningrad (a road and railway line), a fragment of a branching (Ia) of the pan-European corridor I; and

- a fragment of the Warsaw - Gdynia route (only a railway line on the territory of Warmia-Mazuria), a fragment of the pan-European corridor VI.

Listed among the infrastructural priorities of the European Union were only fragments of the Gdynia - Warsaw - Katowice - Vienna railway route (on the territory of Warmia-Mazuria) and the Rail Baltica route from Warsaw to the PolishLithuanian border.
There is only one airport in the voivodeships analysed, at Rzeszów-Jasionka, which serves regular domestic and international flights. For most of the study area, the closest airport is WarsawOkęcie. Plans are made to open airports in Lublin, Białystok and Mazuria.

\section{The socio-economic situation of regions east of the Polish eastern border}

The border regions situated to the north and east of the eastern border of Poland as the outer border of the European Union and the Schengen zone, include the administrative districts ${ }^{1}$ of: Kaliningrad, a Russian exclave on the Baltic Sea, Hrodna and Brest in Belarus, and Lviv, Volyn and Zakarpattya in Ukraine.

Before World War II, the district of Kaliningrad belonged to Germany, those of Hrodna, Brest, Volyn and Lviv - to Poland, and of Zakarpattya - to Czechoslovakia. The taking over of these territories by the Soviet Union in 1945 involved an exchange of the population and the closing of the new Polish-Soviet border, which reduced those areas to a peripheral position in socioeconomic and transport terms. A spectacular example of the population exchange is the district of Kaliningrad, where Germans constituted $99 \%$ of the population in 1939 , while nowadays $78.1 \%$ of the inhabitants are Russians, $7.6 \%$ - Belarusians, $7.5 \%$ - Ukrainians, $1.9 \%$ - Lithuanians, $0.8 \%$ - Armenians, $0.6 \%$ - Germans, and $0.5 \%$ - Poles (Palmowski 2007). In addition, the specific character of the district of Kaliningrad and its inaccessibility are largely due to the military functions it fulfils. On the other hand, in the district of Hrodna (Polish Grodno), despite the resettlement carried out after World War II, a large number of the Polish population has remained, currently amounting to 294,100 persons (while the total number of Poles in Belarus is 395,700), which accounts for roughly $1 / 4$ of the district population (Gniezdowskij, Kosiedowski 2005).

The six districts situated east and north of the eastern boundary of Poland are characterised similarly as the Polish voivodeships considered

${ }^{1}$ A district (oblast') is the counterpart of the Polish voivodeship. 
Table 4. Population of the Regions of Belarus, Russia and Ukraine situated along the border With Poland, 2008

\begin{tabular}{|l|c|c|c|c|c|c|}
\hline \multicolumn{1}{|c|}{ District } & $\begin{array}{c}\text { Population } \\
\text { in '000 }\end{array}$ & $\begin{array}{c}\text { Population } \\
\text { density (persons } \\
\text { per sq. } \mathbf{~ k m ) ~}\end{array}$ & $\begin{array}{c}\text { Population } \\
\text { change } \\
\mathbf{2 0 0 0} \mathbf{1 0 0} \%\end{array}$ & $\begin{array}{c}\text { Index } \\
\text { of urbanisation } \\
\text { in \% }\end{array}$ & $\begin{array}{c}\text { Natural } \\
\text { increase } \\
\text { in \%o }\end{array}$ & $\begin{array}{c}\text { Net } \\
\text { migration } \\
\text { in \%o }\end{array}$ \\
\hline Kaliningrad & 937.0 & 62 & 97.8 & 77.5 & -4.0 & 3.0 \\
\hline Brest' & 1433.1 & 44 & 96.6 & 65.3 & -1.4 & -2.1 \\
\hline Hrodna & 1102.8 & 44 & 93.4 & 68.9 & -3.3 & -3.5 \\
\hline Lviv & 2552.9 & 117 & 97.3 & 60.6 & -2.4 & -0.3 \\
\hline Volyn & 1036.2 & 52 & 97.7 & 51.4 & -0.2 & 0.1 \\
\hline Zakarpattya & 1243.4 & 97 & 97.5 & 37.1 & 1.7 & -1.1 \\
\hline
\end{tabular}

Source: own compilation on the basis of data from the Committees of Statistics of Belarus, Russia and Ukraine.

- by a low population density (except for the district of Lviv), population outflow (except for the district of Kaliningrad) and natural population losses (except for the Zakarpattya district), the latter especially significant in the districts of Kaliningrad and Hrodna (see Table 4).

A characterisation of the economies of the regions studied is made difficult by the incompatibility of the systems of public statistics in Belarus, Russia and Ukraine with the system of the EU statistics.

Keeping in mind the above reservation, it can be stated on the basis of data contained in
Table 5 that the structures of employment in the regions analysed are evidence of their outdated economic structure, this being confirmed in the case of the Ukrainian districts by a high share of employment in agriculture, and in the case of the Belarusian and Russian districts, by high shares of employment in industry, especially the heavy industry linked with the military complex. The low unemployment rates in the districts of Hrodna and Brest are reflections of hidden unemployment rather than of a good situation on the labour market. The estimates of the GDP per capita show the low level of development of the area

TABle 5. INDiCATORS OF THE ECONOMIC DEVELOPMENT OF THE REGIONS OF BELARUS, RUSSIA AND UKRAINE SITUATED ALONG THE BORDER WITH POLAND

\begin{tabular}{|c|c|c|c|c|c|c|}
\hline \multirow{2}{*}{ District } & \multirow{2}{*}{$\begin{array}{l}\text { Share of employed } \\
\text { in total population } \\
\text { number in } 2008\end{array}$} & \multicolumn{3}{|c|}{$\begin{array}{l}\text { Employment structure by sec- } \\
\text { tor of economy in } 2008\end{array}$} & \multirow{2}{*}{$\begin{array}{l}\text { Unemployment } \\
\text { rate in } 2008\end{array}$} & \multirow{2}{*}{$\begin{array}{c}\text { GDP per capita at } \\
\text { purchasing power parity } \\
\text { in } 2006 \\
\text { UE } 27=100^{*}\end{array}$} \\
\hline & & I & II & III & & \\
\hline Kaliningrad & 52.4 & $10.0^{*}$ & $50.0^{*}$ & $40.0^{*}$ & 8.7 & 25.4 \\
\hline Brest & 43.7 & 14.1 & 32.9 & 53.0 & 1.0 & 23.9 \\
\hline Hrodna & 45.5 & 16.1 & 33.3 & 50.6 & 1.0 & 24.6 \\
\hline Lviv & 42.8 & 20.5 & 23.2 & 56.3 & 2.7 & 17.0 \\
\hline Volyn & 42.3 & 31.7 & 15.4 & 52.9 & 4.1 & 15.3 \\
\hline Zakarpattya & 44.4 & 28.5 & 19.5 & 52.0 & 3.0 & 13.2 \\
\hline
\end{tabular}

* Estimates of the authors.

Source: as in Table 4. 
analysed and, in addition, an economic asymmetry with respect to the border areas of Eastern Poland.

The significance of university education in the development of the regions studied is diversified. It is definitely the biggest in the district of Lviv, mainly owing to the city of Lviv itself, the largest academic centre in the entire area analysed, including its Polish, Belarusian, Russian and Ukrainian regions. The 22 university-level schools in Lviv have a total enrolment of 100,500 students (Miszczuk, Trokhimczuk 2005). University education has relatively low significance in the districts of Hrodna, Brest and Zakarpattya, while in the districts of Kaliningrad and Volyn the situation is comparable with the Polish Subcarpathia voivodeship.

In the district of Kaliningrad, which acquired the status of a special economic zone in 1996, a restructuring process takes place in the most important sector of the area, namely manufacturing. This is due to companies with foreign capital participation (German, Polish, Korean, Chinese and American). In this way there have appeared plants producing home appliances, radio and TV equipment, as well as cars. Construction materials and food processing industries develop. On the other hand, metalworking, chemical and oil refining industries have disappeared. Some $40 \%$ of the industrial output of the district is exported. Fishing has a definite, although declining, significance for the economy of the region, while agriculture does not figure prominently.

The Belarusian districts (Brest and Hrodna) are characterised by quite a traditional structure of industry consisting of plants producing machines (machine tools, agricultural machines), transport means (tractors, cars), chemicals (cement, paints) and furniture, processing wood and food, and weaving. Farming also plays a certain role in the economies of both districts. In Brest and Hrodna special economic zones have been established, but their effects are rather limited. Low competitiveness on foreign markets is characteristic of both districts, as demonstrated by just a few percent share of exports in production output.

The Ukrainian districts, especially Volyn and Lviv, have very good conditions for the development of agriculture, and hence this sector of the economy is significant for them. As far as indus- try is concerned, it has quite a traditional structure in the district of Volyn, while in Lviv it undergoes restructuring, owing in particular to the inflow of foreign capital. There are three special economic zones function in these regions, in Kovel (the district of Volyn), Javoriv (Lviv) and in Uzhhorod (Zakarpattya). The competitiveness on the foreign markets of products originating from the districts of Lviv and Zakarpattya is relatively higher; they also have a high natural and cultural potential for the development of tourism.

\section{Transboundary economic relations}

Along with the transformation and decentralisation of the economy in Poland, there has been a de-concentration of various kinds of international connections. This process in Poland coincided with the intensification of the globalisation processes. The opening up of the Polish economic, social and cultural space to international connections has been one of the most dynamic phenomena in the period of transformation (Komorowski 2002). A stepwise intensification of ties has made it possible in some cases to enter a path of quicker growth. It has turned out, on the other hand, to be disadvantageous to have ties (especially economic) with just one foreign partner. Likewise, it is important to have a strong spatial expression of international contacts, as reflected by the greenfield type of foreign investment, long-lasting trade connections, or a steady customer pool in tourist regions.

Poland is characterised by very uneven regional contributions to exports. The regional distribution of the main export centres after the country's accession to the European Union has remained almost unchanged, although a distinct diffusion of the export activity into the more peripheral areas could be observed, especially in central and south-eastern Poland. In the case of imports, the analogous phenomenon of de-concentration has been much less pronounced (Komornicki 2007).

In 2005 and 2007 there was a distinct increase in the significance of export connections with the European Union in eastern Poland. This took place both owing to the general increase in the export value and owing to the enlargement of the 
Union itself (in some eastern regions there was a concentration of trade with such countries as Lithuania, Slovakia and Hungary, now EU members). In relative terms, the increase in exports to the EU countries was the highest in the east. At the same time, western Poland opened up to trade with third countries. Thereby, a partial evening out of the disproportion in the trade structure between the eastern and the western halves of the country took place.

The distribution of trade flows with the three eastern neighbour countries differs widely in space and time. At the scale of the country, the eastern partners nowadays play the most pronounced role in the exports of Podlasie (close to 23\%), Subcarpathia and Mazovia. On the other hand, their significance is marginal (below 5\%) in the voivodeships of Lower Silesia, West Pomerania and Opole. The joint share of these three countries in the Polish exports increased from $6 \%$ in 2000 to $8.3 \%$ in 2005 and then close to $9 \%$ in 2007. The biggest increase in this share in the study period was observed in Lubuska Land, Świętokrzyska Land and Podlasie, while a characteristic fast drop occurred in Lublin voivodeship. Yet in the year 2000 this voivodeship generated $9 \%$ of exports to Russia, Ukraine and Belarus, while in 2007 , only close to $3 \%$. At the same time, there was an increase in the east-bound exports by Mazovia (up to 33\% in 2007), Silesia, Wielkopolska and Lower Silesia. Summing up, it can be stated that although the eastern partners still play a relatively more important role in the eastern voivodeships, the biggest outward flows in this direction have moved away from the direct vicinity of the border towards the main exporting areas of central and western Poland.

Yet in 2000 the four analysed eastern voivodeships were the area of a very strong concentration of export to the directly neighbouring countries. This applied, in particular, to the exports to Ukraine (see Fig. 1), which were concentrated in

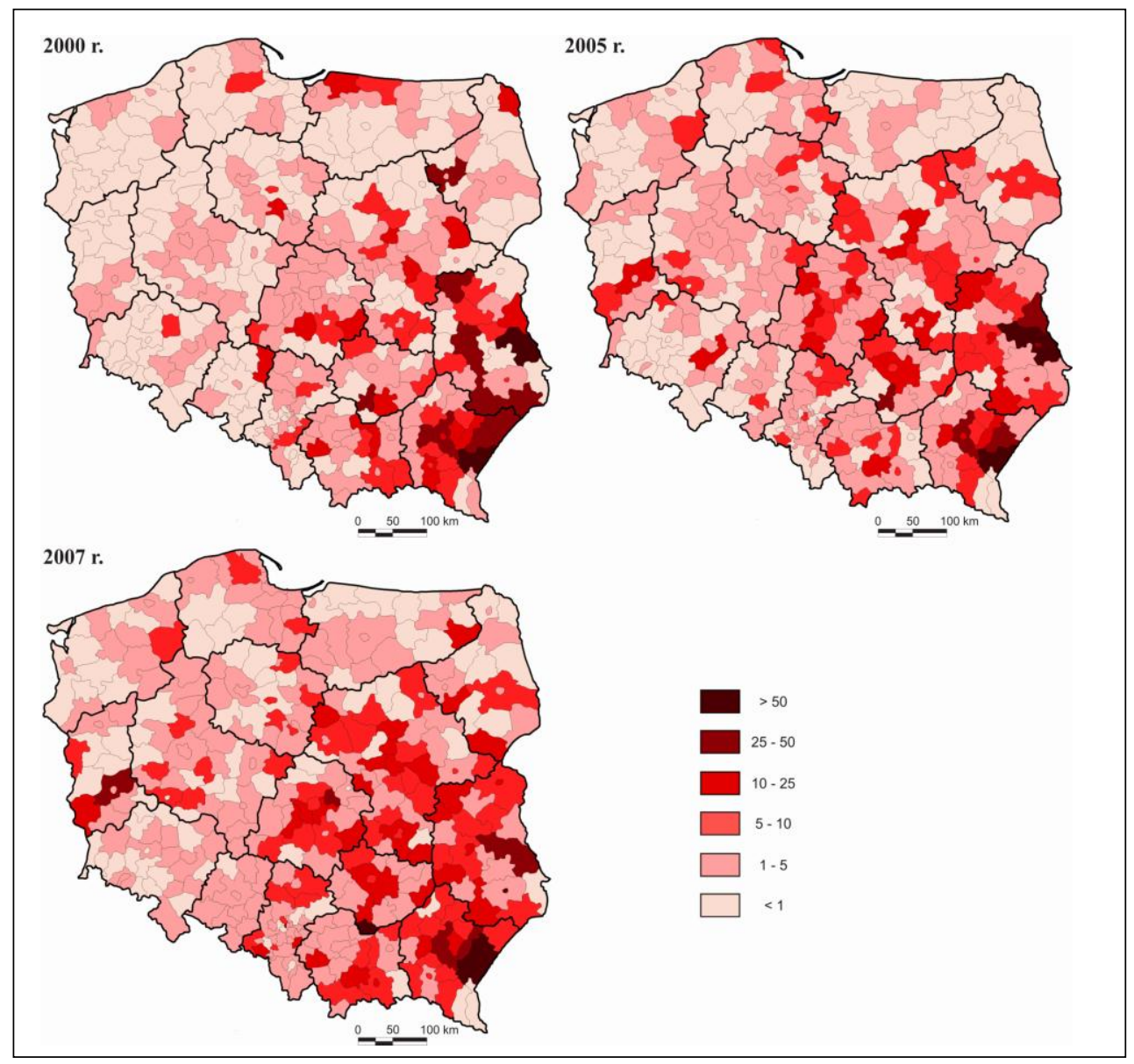

Figure 1. The share of Ukraine in Polish exports $(2000,2005,2007)$

Source: own compilation based on materials from the Polish Ministry of Finance 
Lublin and Subcarpathia voivodeships. The reasons for such a state of affairs should be sought in lower quality requirements of the Ukrainian or Belarusian markets. Numerous small businessmen from eastern Poland could not stand the challenge of the EU market competition, while their not always quite modern products could still be sold in the East. A part of the effect ought also to be attributed to the location in the vicinity of the border of companies re-exporting goods first imported to Poland (e.g. Ukraine imports coffee and bananas from Poland; Komornicki 2007). However, in the years 2000-2007 there was a decrease in export to Ukraine from the borderland area (the voivodeships of Lublin and Subcarpathia).

A specific form of economic contacts at the local scale is the near-the-border trade and services. This phenomenon is investigated both as part of tourist studies and in more general economic terms. During almost the whole decade of the 1990s, the turnover of the Polish borderland bazaars compensated for the deficit in the official foreign trade. This fact was largely due to enormous differences in the levels of income of the population and in prices, both between Poland and Germany and between Poland and the former USSR republics (Powęska 2002). Nowadays, the significance of bazaar trade is distinctly lower, due, in particular, to the evening out of the prices and to changes in the customs policies of the neighbouring countries.

\section{Border traffic}

During the entire period of the transformation, and especially in the 1990s, the number of border crossings quickly increased in Poland. The dynamics in this domain, however, was lower at the eastern boundary. After the main routes had been opened to traffic, successive border crossings were set up less and less frequently. There are still many hard-surfaced roads that cross the border, but actual crossing is not allowed there. At the moment of enlargement of the Schengen zone (December 2007), there were 14 generally accessible road border crossings on the Polish segment of the outer boundary of the European Union (of which one crossing at the Belarusian border was meant only for the citizens of the two neighbouring countries, see Table 6). Besides, there was one road crossing meant solely for cargo traffic, and two Polish-Belarusian tourist crossings (for boats on the Augustów Canal and for tourists walking in the Białowieża Forest, both functioning for only a couple of hours a day). Heavy-load road traffic could cross the border without any limitations at seven points

Table 6. Transborder road infrastructure in Poland (EU EXTERnal Land border) in 2008

\begin{tabular}{|c|c|c|c|c|c|c|}
\hline $\begin{array}{l}\text { Border } \\
\text { with: }\end{array}$ & $\begin{array}{l}\text { Length of } \\
\text { border } \\
\text { in km }\end{array}$ & $\begin{array}{l}\text { Number of } \\
\text { hard-surfaced } \\
\text { roads } \\
\text { crossing the } \\
\text { border }\end{array}$ & \begin{tabular}{|} 
Length of \\
border segment \\
per hard- \\
-surfaced road \\
in $\mathrm{km}$
\end{tabular} & $\begin{array}{l}\text { Number } \\
\text { of generally } \\
\text { accessible } \\
\text { border } \\
\text { crossings }\end{array}$ & $\begin{array}{l}\text { Length } \\
\text { of border } \\
\text { segment per } \\
\text { generally } \\
\text { accessible } \\
\text { crossing }\end{array}$ & $\begin{array}{c}\text { Degree } \\
\text { of use } \\
\text { of transborder } \\
\text { roads for } \\
\text { crossing the } \\
\text { border (in } \% \text { ) }\end{array}$ \\
\hline RUSSIA & 210 & 17 & 12 & 3 & 70 & 18 \\
\hline BELARUS & 418 & 14 & 30 & 5 & 84 & 36 \\
\hline UKRAINE & 535 & 11 & 49 & 6 & 89 & 55 \\
\hline Total & 1163 & 42 & 28 & 14 & 83 & 33 \\
\hline Lviv & 42.8 & 20.5 & 23.2 & 56.3 & 2.7 & 17.0 \\
\hline Volyn & 42.3 & 31.7 & 15.4 & 52.9 & 4.1 & 15.3 \\
\hline Zakarpattya & 44.4 & 28.5 & 19.5 & 52.0 & 3.0 & 13.2 \\
\hline
\end{tabular}

Source: own elaboration on the basis of materials from the Border Guard. 
(three Polish-Belarusian and four Polish-Ukrainian), at the remaining ones (including all of the Polish-Russian ones) there was a limitation on the total weight of the vehicle.

Of the fourteen official railway crossings, regular passenger traffic took place at only seven. The significance of railway in bilateral passenger traffic between Poland and its eastern neighbours quickly decreased during the transformation period. Its relatively stronger position only persists because of the very low throughput capacity of the road crossings, and partly also because of the apprehensions of the Polish citizens as to travelling by a car of one's own through the countries of the former USSR (a more or less justified fear of bad road conditions, corruption among the police, and criminal activity).

The turn of the 1990s was the period of extremely dynamic increase in the cross-border traffic, of both people and vehicles, through the eastern border (see Figure 2). Human traffic reached its first peak in 1991 when only the border with Ukraine was crossed by close to 7.4 million people in both directions This was the period immediately after the border had been opened to mass traffic. Price rises in Poland resulting from the transition to a market economy made petty trade attractive; it consisted in cheap products of the declining Soviet economy being brought to Poland and sold at Polish bazaars. At the same time, many Poles decided for the first time to visit the historical and family relics in the former Polish eastern borderland (Komornicki 1999).

The years to follow brought, however, a slow decrease in the intensity of traffic. The primary reason was the worsening of the economic situation in Belarus and Ukraine (separation from Russia, beginning of the economic reforms). There were significant increases in prices of consumer goods. Simultaneously, the situation in Poland kept gradually improving and the number of customers at the bazaars dropped. Consequently, the profitability of the petty 'tourist' trade decreased. There was also a slow decrease in the number of Poles travelling to the east. The years 1994-1997 were a period of a new, very intensive increase in traffic, though applying exclusively to foreigners. The direction of the cross-border trade changed, as well. Ukrainians,
Belarusians and Russians started to come to Poland to do shopping. At the same time numerous citizens of Romania started to come to Poland through the Polish-Ukrainian border (they were mostly Gypsies, trying thereafter to make their way to Western Europe). Then there was a second breakdown in the traffic, which took place due to the Russian crisis with its severe impact on the entire territory of the former Soviet Union. This was followed by another wave of development of cross-border trade which occurred in the years 1999-2001. There was also, again, an increase in the number of Poles travelling to Ukraine (a bigger number of business trips, intensification of tourism, in particular to the Ukrainian spas). After 2003, when visas were introduced, the number of visitors from abroad dropped abruptly, while, unexpectedly, the popularity of travelling to the east (especially to Ukraine) quickly increased among Poles. This was associated, in particular, with a fast increase in fuel prices in Poland (despite the queues at the border crossings it became worthwhile to go across the border to fill vehicle tanks with fuel). The customs limitations, successively introduced by the Ukrainian authorities and reducing the profitability of shopping in Poland, also exerted a significant influence. In the consecutive years the situation along the particular fragments of the borders got significantly diversified. A hardly predictable dynamics took place at the border with Ukraine. In 2006 this border was crossed in both directions by close to 20 million persons - almost twice the number from the period of the highest bazaar prosperity of the mid-1990s. A slight increase in the number of persons crossing the border with Belarus was also noted, to the level of roughly 10 million. The year 2007, which had immediately preceded the extension of the Schengen zone, brought, on the other hand, a decrease in traffic across all the three segments of the outer boundary of the European Union. In the case of the border with the Kaliningrad district, this was a continuation of the trend started two years before. In 2008, we can speak of a true collapse of the bilateral movement of persons at the borders with Belarus and Ukraine. In the case of Belarus the traffic dropped below the level registered in 1990. 


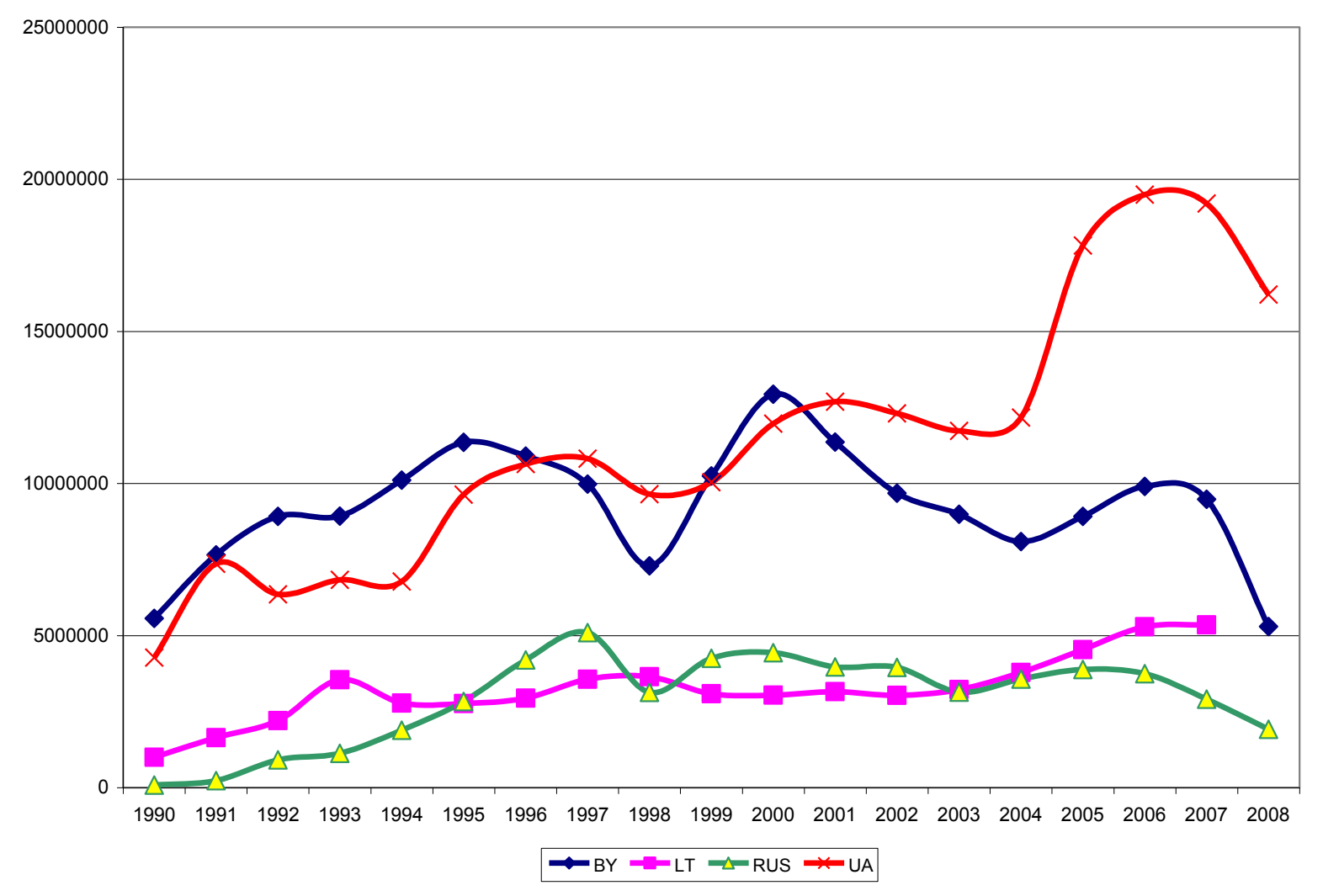

Figure 2. Traffic of persons across the Polish eastern border according to segments, 1990-2008 Source: own compilation on the basis of data from the Border Guard Headquarters

The traffic of trucks (HGV; see Figure 3) across the Polish eastern border had been increasing steadily since the collapse of the Soviet Union (the years 1990-1992) until 1997. In the years 19981999 there was a short-lived breakdown associated with the already mentioned Russian crisis, and then further rapid intensification. The 1998 breakdown was clearly smaller on the Ukrainian than on the Belarusian border. The period of regression was, on the other hand, much longer for the vehicles with Polish registration plates than for foreign registrations (Ukrainian, but also Russian, Romanian and Bulgarian in the transit traffic). The number of Polish trucks crossing the Ukrainian border exceeded the 1996 level only in 2002. After 2002, however, the increase in this group was more dynamic than for the foreign trucks. It should be remembered, though, that the distinction between the vehicles with Polish and foreign registration is not too precise. In practice, a vehicle registered in one country may belong to a company from another country, and the driver may be a citizen of yet another country.
The dynamics of traffic growth (especially on the Ukrainian border) exceeded the dynamics of foreign trade, which is evidence of both, a high share of transit traffic and of a gradual increase in the share of road transport in Polish foreign trade. After 1998, on the eastern border, the crossing at Kukuryki (the Warsaw-Minsk-Moscow corridor) ceased to be the most intensively used one in cargo traffic. Currently, cargo traffic is decidedly more intensive at the Budzisko crossing on the Lithuanian border (Via Baltica; Warsaw-Tallinn). There was also a relative increase in the role, in this respect, of the PolishUkrainian border crossings, especially the one in Dorohusk (Warsaw-Kiev).

The absolute increments in the border traffic of heavy loads after Poland joined European Union (2004-2006) concentrate in a distinct manner in just a couple of points. These are, first of all: Budzisko on the Lithuanian border (Via Baltica), Świecko on the German border (Warsaw-Berlin) and Cieszyn on the Czech border (WarsawVienna). These three border crossings account 


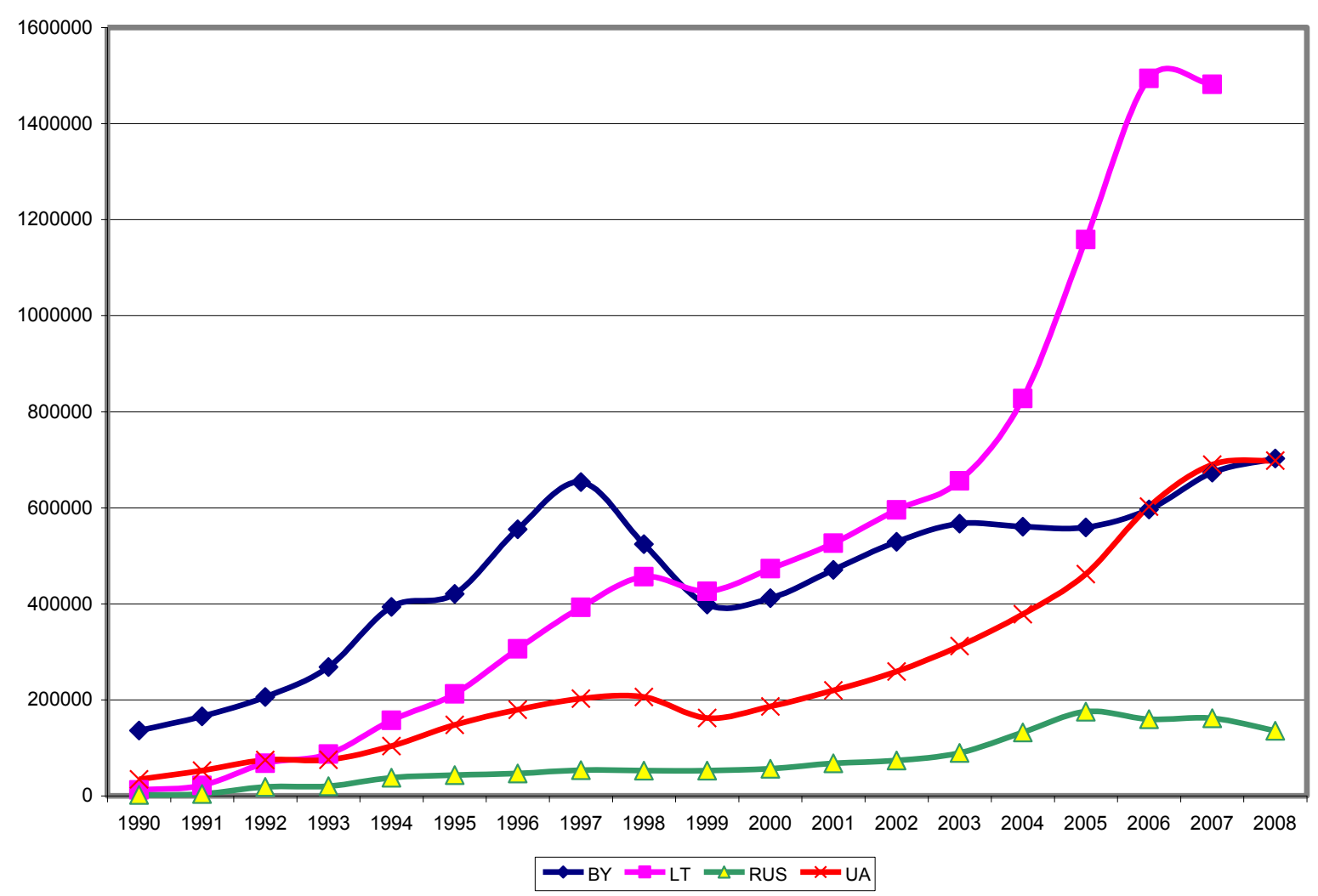

Figure 3. HGV traffic across the Polish eastern border, 1990-2008.

Source: own compilation based on the unpublished Border Guard materials

currently for more than $50 \%$ of the entire border traffic of trucks. There has also been a relative increase in these terms of the role of the PolishUkrainian crossings, especially the ones in Dorohusk (Warsaw-Kiev) and in Korczowa (CracowLviv). The year 2008 and the membership of Poland in the Schengen zone have not influenced in any significant manner the upward trend of traffic across the Belarusian and Ukrainian borders, and the downward trend in the case of the Russian border.

The economic advantages from the generation of the transit flows give rise to doubts and have been in a clear manner overestimated during the entire period of transformation. Adaptation of the planned modern network of roads for the needs of transit became one of the reasons of delays in the implementation of the respective investment projects. It was also conducive to the intensification of conflicts associated with the course of the new roads.

\section{Summary}

The considerations, presented here by the authors, lead to several general conclusions, concerning the state and the development perspectives of the areas in question:

- regions situated on both sides of the Polish eastern border are characterised by depopulation, lower level of development than on the average in the respective countries, quite traditional structure of employment, with relatively high share of both agriculture and industry, and by the economic asymmetry to the advantage of the Polish regions;

- accession of Poland to the European Union, and to the Schengen zone, signifies an enhancement of the socio-economic cohesion also of her eastern regions; this process is accompanied, though, by the reduction of the transboundary interactions, which locally (and probably transitorily) may result in the worsening of the economic conditions; 
- the future of the eastern voivodeships of Poland depends largely upon the choices, made by Russia, Belarus and Ukraine, as well as upon the future regional policy of the EU; according to ESPON three scenarios are hypothetically possible in this respect up till the year 2030 (Scenarios ..., 2007); in the case of the cohesion scenario, there shall follow a gradual increase of the investment attractiveness, and thereby also the development of eastern Poland; in the scenario being the extrapolation of the trends to date the areas will develop situated along the main road routes A2 and A4, while in the scenario based on competitiveness - entire Poland remains a peripheral area of the EU. Scenarios identified in ESPON, though, constitute, a false alternative; the cohesion scenario, most advantageous for eastern Poland, assumes stopping the EU enlargement and lack of deepening of cooperation with direct neighbours; the analysis here presented demonstrates, on the other hand, that for the areas considered such a cooperation is an essential development factor;

- the effects of accession to the European Union were unequivocally positive for the economies of the voivodeships studied; this is proven by the intensification of exports to the so-called "demanding markets" with simultaneous slowdown of the upward tendency in the domain of the share in imports from Western Europe; at the same time, however, comparison with other regions of the country proves that the potential associated with accession has been used in the East to a relatively smaller degree;

- in the years 2007-2013, owing to the allocation of means from the Structural Funds, worth around 26 billion $€$ for the area of eastern Poland, there shall certainly follow a great progress, both in the sphere of infrastructure and in the quality of human resources, which constitutes an opportunity for a significant raising of the economic development level;

- the here analysed voivodeships of Eastern Poland play to an increasing degree the supraregional and international functions; their development requires, therefore, better infrastructural connections with central Poland and farther - with the inside of the European Union; still, in the provincial development strategies and in other planning documents the development opportunities are seen primarily in the servicing of transit and in local transboundary cooperation; the external costs of the heavy road traffic in transit (environmental and linked with the consequences of road accidents) nullify, namely, to a large extent, the profits connected with servicing of such traffic (Węcławowicz et al., 2006); lower significance ought also be attached to the currently frequently repeated postulate of opening up new border crossings with the eastern neighbours; it is, namely, more important to try to improve the system of customs and border controls; without a shortening of these procedures construction of the consecutive border crossings shall not reducee the significance of the eastern boundary as a spatial barrier.

\section{References}

Gniezdowskij J.J., KosiedowsKi W., 2005, Wstępna ocena konkurencyjności obwodu grodzieńskiego Republiki Białoruś jako regionu przygranicznego. Przeglad Polityczno-Gospodarczy Europy Środkowej i Wschodniej, 12: 163-172.

HARSTHORNE R., 1936. Suggestions on the terminology of political boundaries. Annals of the Association of American Geographers, 23: 195-228.

KalinOwsKi T. (ed.), 2007. Atrakcyjność inwestycyjna województw i podregionów Polski 2007. IBnGR, Gdańsk.

KomornicKi T., 1999. Granice Polski. Analiza zmian przenikalności w latach 1990-1996 (Boundaries of Poland. Analysis of changes in permeability in the years 1990-1996). Geopolitical Studies Vol. 5, IGiPZ PAN, Warszawa.

KOMORNICKI T., 2007. External border of the European Union - permeability, co-operation, perspectives. In: A. Kovacs (ed.), Regionality and/or Locality. Discussion Papers, Centre for Regional Studies, Hungarian Academy of Sciences, Pecs: 89-103.

KOMOROWSKI J., 2002. Internacjonalizacja miast i jej uwarunkowania w Polsce. In: J. Słodczyk (ed.), Przemiany bazy ekonomicznej i struktury przestrzennej miast. Uniwersytet Opolski, Opole: 97-112.

LIJEWSKI T., 1986. Geografia transportu Polski (Transport Geography of Poland). PWE, Warszawa.

Miszczuk A., Trokнimczuk S., 2005. Science and Higher Education. In: B. Kawałko, A. Miszczuk (eds), The Polish-Ukrainian Borderland. Environment. Society. Economy. College of Management and Administration, Zamość: 153-162. 
MoraczewSKA A., 2008. Transformacja funkcji granic Polski. Wydawnictwo UMCS, Lublin.

Palmowski T., 2007. Współpraca z Obwodem Kaliningradzkim Federacji Rosyjskiej jako czynnik rozwoju regionalnego. In: Ekspertyzy do Strategii Rozwoju SpołecznoGospodarczego Polski Wschodniej do roku 2020. Ministerstwo Rozwoju Regionalnego, Warszawa, 2: 71-107.

POWĘSKA H., 2002. Przestrzenny wymiar handlu transgranicznego w Polsce w ostatniej dekadzie XX wieku. Geopolitical Studies, 9, IGiPZ PAN, Warszawa.
RościszewSKI M., 1993. Polska i jej uwarunkowania geograficzno-polityczne (Poland: Geographical and Political Condition). In: Conference Papers IGSO PAS, 17: 37-86.

Scenarios on the territorial future of Europe, 2007, ESPON, Luxemburg.

WęcŁaWOWicz G., BAŃSKi J., DegóRSKi M., KOMORNicKi T., KorCelli P., ŚleszyńsKi P., 2006. Przestrzenne Zagospodarowanie Polski na poczatku XXI wieku. Monografie IGiPZ PAN, Warszawa. 